\title{
Perspectives of E-health Interventions for Stress-Related Disorders: A Critical Review
}

\author{
Jonas EIMONTAS ${ }^{1}$, Goda GEGIECKAITĖ, Paulina ŽELVIENĖ \\ Vilniaus universitetas
}

\begin{abstract}
The aim of this paper is to review the current status of e-health interventions and discuss the main controversies and issues related to e-health definitions, forms of IT-based interventions, limitations and advantages, as well as directions for future research. Alongside the benefits that rapid development of ITbased psychosocial interventions bring to the mental health care system, they also bring challenges for patients, professionals, and researchers in the field in regard to methodology and terminology. There is also a huge variety of different forms of IT-based interventions. The popularity of these interventions is growing because of their convenience, cost-effectiveness, fewer stigmas attached to them, and other benefits. On the other hand, there are legal, ethical, confidentiality, and other questions that need to be considered. IT-based interventions for stress-related disorders share all of these difficulties. However, we also need to look at problems that come from dealing with a specific disorder. Research of IT-based interventions for stressrelated disorders confirms their effectiveness but also shows that their effectiveness can depend on the user's and intervention's qualities, hence more research on these variables is needed.
\end{abstract}

Keywords. E-health, intervention, IT-based intervention, stress-related disorders

\section{Introduction}

The importance of information technology (IT) in people's everyday life is growing continuously. The benefits of IT are used more and more by the health care system, therefore, new terms and definitions are created, and with that comes a fair amount of confusion (Eysenbach, 2001). When the e-mail and programs like Skype were found, the possibility of counselling clients that are far away was created. In this way, when a client or a psychologist has to move for some reason, it is possible to continue the process of counselling.

When smartphones and tablet computers emerged in the market, various self-help and guided applications for mobile devices have been introduced. Researchers are looking for ways in which a person in need for psychological help, but without possibility of getting it, could help himself or herself (Kazdin \& Rabbitt, 2013). Also various internet and mobile device applications are offered to clients as an additional tool alongside the ongoing therapy. In countries around the world, cognitive behavioural therapy-based self-help programs are started to be integrated into health care systems for people on the waiting lists for the psychologist services.

In addition to the programs created by professionals, self-help websites and forums created by clients themselves are gaining popularity. IT-based psychosocial interventions are a relatively new research topic, that has grown mostly in the last 10-15 years, therefore, researchers and practitioners are continuously raising new questions about e-health possibilities and challenges (Barak, Hen, Boniel-Nissim, \& Shapira, 2008; Griffiths, 2001). The new definitions and research methodology problems that came along with the rapid development of IT-based interventions still need to be unified, systemised, and understood. There are even more things to consider when psychologists are trying to apply internet-based interventions to specific disorders. Stress related disorders are distinguished from other disorders by having a clear event that elicits stress, thus it is important to consider what is necessary for the treatment of this disorder.

The aim of this paper is to review the current status of e-health interventions and discuss the main controversies and issues related to the e-health definitions, forms of IT-based interventions, limitations and advantages, as well as directions for future research. 
ISSUES IN E-HEALTH INTERVENTIONS FOR STRESS

\section{E-health and forms of interventions}

\subsection{Issues in e-health terminology}

As technology is developing further, so are the mental health services. New technologies are bringing new ways of delivering help and with that comes a lot of new definitions. New innovative research is being conducted at the same time in different countries, therefore, researchers themselves have to name the methods and interventions they are creating and using. This creates some problems with terminology because when terms, such as e-counselling, cybercounselling, teletherapy, e-therapy, internet-based psychotherapy, and internet-based treatment are used in the literature, they often, but not always, have the same meaning, which creates confusion in the research field (Anderson et al., 2012; Barak et al., 2008; Maheu, Pulier, Wilhelm, McMenamin, \& Brown-Connolly, 2004). E- health is one of the most convenient terms, because it's broad enough to include all kinds of IT and interventions. It is best represented by the definition created by Eysenbach (2001):

E-health is an emerging field in the intersection of medical informatics, public health and business, referring to health services and information delivered or enhanced through the Internet and related technologies. In a broader sense, the term characterizes not only a technical development, but also a state-of-mind, a way of thinking, an attitude, and a commitment for networked, global thinking, to improve health care locally, regionally, and worldwide by using information and communication technology ("Introduction", para.3)

The author is hoping that this definition is broad enough to apply to a dynamic environment, such as the Internet, and at the same time acknowledges that e-health encompasses more than just "Internet and Medicine". Letter e stands for electronic. Meanwhile Maheu, Pulier, Wilhelm, McMenamin, \& Brown-Connolly (2004) state that ehealth is a term that includes all kinds of internet-based telehealth (professional, non-professional, educational, informational, and commercial services offered by companies and clients themselves).

\subsection{Forms of IT-based interventions}

There are many forms that IT- based intervention can take. There is no definite classification of the forms of IT-based interventions, but it is very important when it comes to research and trying to compare how effective different interventions are and what role the form of intervention plays in its effectiveness.

Suler (2000) suggested a classification of a 5-dimensional model of the internet and computer-based psychotherapies. All five dimensions are continuums that can overlap:

1. Synchronous/asynchronous. Asynchronous communication involves communication that is not happening "live" but when both sides can respond whenever. Synchronous communication allows more improvisation and the possibility of getting information spontaneously. The advantage of asynchronous communication is the opportunity for the client to express themselves freely without being interrupted, to have time to think.

2. Text/sensory. For the sensory-rich communication (e.g., Skype conversation) to happen, a well operating equipment is needed, which allows the therapist to access very valuable information of body language. Meanwhile, text conversations have an advantage of being more convenient, anonymous, and easy to archive.

3. Imaginary/actual. The best example of actual communication is audio-visual conferencing. Imaginary communication can take forms of text and visualisation using multimedia.

4. Automated/interpersonal. Automated means are less expensive, more accurate, and objective. Meanwhile, interpersonal communication is more empathic, creates a bond.

5. Invisible/present. Invisible in intervention can be either one or everyone: the therapists, clients, supervisors. But invisibility is connected to ethical dilemmas. The most present communication happens when it is synchronous and sensory-rich.

There are also more specific ways to categorize IT-based interventions. Sarasohn-Kahn (2012) in his comprehensive review of IT-based interventions suggested categories of: computer-based cognitive behavioural therapy, online counselling, online social networks, mobile platforms for self-tracking and support, games for behavioural health, and virtual reality.

\section{E-health advantages and limitations}

The usage of IT in mental health care has a lot of benefits, but also a considerable amount of problematic questions concerning the delivery of the IT-based services. Usually, the same characteristics of e-health that create its biggest 
potential, such as being able to use it remotely, also create some limitations that are less problematic in the traditional health care, such as ensuring intervention is provided and used appropriately.

Table 1. E-health advantages and limitations.

\begin{tabular}{ll}
\hline Advantages & Limitations \\
\hline Convenience & Legal and ethical problems \\
Cost-effectiveness & License requirements \\
Accessibility & Effectiveness \\
Disinhibition & Confidentiality \\
Fewer stigmas & Technological difficulties \\
Global & Payment \\
& Identification \\
& Directing a client \\
\hline
\end{tabular}

\subsection{Advantages}

- Convenience. If it is an IT-based counselling with a professional, then convenience stems from the fact that the client and the therapist do not have to agree on a specific time for a session (if communication is asynchronous).

- Cost-effectiveness. When compared to traditional therapy, the internet-based therapy is cheaper and gives an opportunity to clients to get help or advice quickly and in confidence.

- Accessibility. The Internet-based therapy creates an opportunity to get help for people who would otherwise be unable to access therapy for various reasons. First of all, there are people that live in remote areas and have disabilities that limit their ability to move.

- Disinhibition. The Internet has the effect of creating disinhibition and lessening social desirability (Joinson, 1998). As a result of this, people in the IT-based intervention might be more open, creating more validity.

- Fewer stigmas. The possibility of getting help anonymously through internet lessens the effect of stigma and could encourage some people to seek for needed help online (Griffiths, 2001).

- Global. The World Wide Web has no borders. This allows therapists to reach clients in any part of the world. If there is no language barrier, then any person can become a potential client (Griffiths, 2001).

\subsection{Limitations}

- Legal and ethical problems. The Internet is used all around the world without borders, but different countries have different laws for mental health care. This raises difficult questions: can an unlicensed specialist provide services in a country that requires a license, and in which country should the taxes be paid? Who would be responsible for the harm caused by an unprofessional practice and how would they be penalized?

- License requirements. One of the ways for a client to know how competent the psychologist providing the services online is to check if he or she belongs to associations that accept only qualified professionals. But when it comes to self-help programs, either without a therapist or only involving a consultant to guide the client on how to use the program, then it is especially hard to measure the professional quality of the intervention.

- $\quad$ Effectiveness. The elements that make traditional therapy effective will not necessarily be relevant and work in IT-based interventions (Barak et al., 2008). The therapeutic alliance between a therapist and a client has a very big importance in traditional therapy, but in the IT-based interventions, a therapist might be not involved at all. 
- $\quad$ Confidentiality. The mental health care providers might be interested in saving money and be reluctant to invest in the safety ensuring technologies. This creates a danger of databases and intervention websites being hacked and the personal data being exposed.

- Technological difficulties. The servers storing IT-based interventions can go down and the technology used by a client to access intervention might also break down. All of these reasons can put the process of intervention in danger.

- Payment. When it comes to paid interventions, we come across another limitation: international payment for services can be complicated, a different kind of transfers and accounts are needed (Griffiths, 2001).

- Identification. When applying intervention remotely, the issue of identifying who is the user of the intervention comes up (Griffiths, 2001).

- Directing a client. There is no clear system, which would help with directing a client to a required specialist.

- Adherence. Melville, Casey, \& Kavanagh (2010) carried out a literature review on the dropout from the internetbased treatment for psychological disorders. The dropout was between 2 to 83 percent, and the average was 31 percent. In the analysed studies, different variables that could influence premature termination from the IT-based interventions were examined, but authors concluded that there are no definite answers what makes a user drop out of the IT-based interventions (Melville et al., 2010).

Many of the advantages of e-health are important enough to realize why it is gaining such a popularity these days. Even though there are a considerable amount of limitations at this time, many of them could be overcome with further research or considerations when creating new interventions or even global guidelines of e-health.

\section{E-health research directions in interventions for stress-related disorders}

\subsection{Specificity of IT-based interventions for stress related disorders}

When it comes to IT-based interventions, same as with any kind of psychological help, for better understanding of its effectiveness, value and how it works, it is important to consider the particulars of specific disorders. The IT-based interventions are non-traditional tools for psychological help that are missing or, on the contrary, have some elements not included in the usual therapy, therefore, it is important to understand how this might affect the treatment of a specific disorder.

Stress-related disorders are connected to a specific stress-eliciting event. Everyone is experiencing stress evoking circumstances almost every day, but stress that comes with some incidents can reach a level of adaptation disorder, start to disrupt usual functioning and last up to six months, or a person after trauma can experience posttraumatic stress that seriously limits normal functioning and can last for years when not treated.

As mentioned above, specific events provoke stress-related disorders, so interventions that focus on working with a stress eliciting event and its consequences have the most evidence of effectiveness. Usually, it is cognitive behavioural therapy for PTSD, focusing on working with trauma (Bisson, 2007). Most of the interventions for stressrelated disorders and especially PTSD are also based on the principle to work with a stress eliciting event, but adapts them to computerized environment or internet (Lange, Ven, \& Schrieken, 2003; Litz et al., 2014; Spence et al., 2011). These principles are a habituation to the frightening stimuli that occur after exposure to the traumatic memories and avoided stimuli, cognitive reappraisal of the traumatic experiences, and social sharing and support (Lange et al., 2003).

\subsection{Research of the effectiveness of the interventions}

With the growing use of technology in psychology, the question of which interventions are the best is starting to be more and more important for researchers and practitioners. This question arises when an intervention has to be chosen for research and also when dealing with practical problems, such as which intervention to recommend for a client who does not have the opportunity for traditional therapy.

Barak and colleagues (2008) made a meta-analysis of internet-based psychotherapies that showed that internet-based therapy is a very appropriate way to treat PTSD. The calculated average effect size of all interventions for PTSD were $d=0.88$, which shows high effectiveness and is equally effective and, in some cases, more effective than traditional interventions (Barak et al., 2008). The study also showed that the most effective interventions are interventions based on cognitive behavioural therapy, with the average effect size $d=0.83$. Although these interventions are not very effective for children to 18 years of age $(d=0.15)$. This meta-analysis showed that interactive websites were statistically significantly more effective than static websites $(d=0.65$ and $d=0.52)$. This 
difference could also be because interactive websites are usually based on CBT, while static websites are more psychoeducational. Another statistically significant difference was found between closed and open websites. It is thought that closed websites have the advantage of requiring users to do assessments before starting the program. This can help in convincing of websites trustworthiness and the effort put into registration and selection process can motivate the client to continue using the program.

We can conclude that internet-based interventions are effective on treating people with PTSD. Studies show that the most effective are closed interactive websites based on cognitive behavioural therapy and intended for adults.

\subsection{Research on the variables making interventions effective}

We already discussed that IT-based interventions for PTSD can be effective. But when creating new IT-based interventions, it is important to know what variables make intervention effective.

Andersson, Carlbring, Berger, Almlöv \& Cuijpers (2009) state that there are a few variables mostly influencing effectiveness of therapy:

- Specificity of the therapy. Therapy created for a specific disorder and for an accurate diagnosis is the most effective.

- Content in the intervention should be comprehensive and diverse.

- $\quad$ Periods between sessions should be long enough (Andersson et al., 2009).

It is not always possible to integrate the indicated variables into the public health perspective based on open IT interventions, because:

- These interventions focus not only on the removal of specific symptoms, but also on unveiling the available psychological resources of the client and teaching to use them appropriately.

- $\quad$ Client can use intervention whenever time he or she needs it.

Other researchers emphasize the importance of the therapeutic relationship in IT-based interventions. Wagner, Brand, Schulz, \& Knaevelsrud (2012) found that it is possible to create a stable and strong therapeutic relationship through internet, which can predict the intensity of PTSD symptoms in the end of the therapy. But not all IT-based interventions are designed to have a psychologist, a consultant or a helper. The future researches have an important task to study the clients' and the IT-based automatic programs' interaction and relation, its features and influence on effectiveness of intervention.

Research also shows that users with stress-related and anxiety disorders have the same problem related to ITbased psychosocial interventions like other users - a large number of them drop out and do not finish the program. Studies of online interventions for anxiety and depression show that the attrition is usually from $20 \%$ to $40 \%$, but there are interventions that reach 99\% (Al Asadi, Klein, \& Meyer, 2014; Andrews, Cuijpers, Craske, McEvoy, \& Titov, 2010).

This remarkably high percent of attrition is usually linked to automatic and open to everyone interventions. For example, in an open online self-help program for panic disorder, only 12 of 1161 participants finished the whole 12-week program (Farvolden, Denisoff, Selby, Bagby, \& Rudy, 2005). The more people having stress-related disorders will adhere and use IT-based interventions, the less of them will drop out and more people will get the help they need. Therefore, it is important to study not only the effectiveness of the interventions, but also what makes participants to adhere to IT-based interventions.

\section{Conclusions}

E- health is a rapidly growing field, in fact, at times it's growing too fast for researchers to create a more unified research field. Many different terms are used in the field, only creating more difficulties to systemize research. Ehealth is one of the broadest terms to describe different types of treatment based on IT, but more agreement on terms for more specific types of interventions is needed. Another important issue is to establish categories of intervention forms in order to make research more effective and more comparable between each other. Suler's (2000) suggested a 5-dimension model is pretty extensive and could offer guidance in future research trying to categorize and compare different interventions. IT-based interventions have relevant advantages to become an important part of mental health care, but legal, ethical and adherence problems need to be considered as well as how to ensure quality services. At the 
moment, these can be serious limitations of IT-based interventions, but as this field progress some future established guidelines could help resolve many of these issues.

IT-based interventions for stress-related disorders gain more and more attention and studies show the potential of their effectiveness, but there are also problems like low adherence and attrition. For IT-based interventions to become part of mental health care system, it is necessary to continue research on different interventions, their effectiveness and cost-effectiveness, it is important not only to continue improving them and making them more effective but also more attractive for the users, as it seems that big attrition is one of the most consistent problems of these interventions.

\title{
Acknowledgements
}

This research was funded by a grant (No. MIP-079/2014) from the Research Council of Lithuania.

\section{E. sveikatos intervencijų esant stresiniams sutrikimams perspektyvos: kritinė apžvalga}

\author{
Jonas EIMONTAS ${ }^{l}$, Goda GEGIECKAITE், Paulina ŽELVIENE் \\ Vilniaus Universitetas \\ ${ }^{1}$ Kontaktinis asmuo: jonaseimontas@gmail.com
}

\begin{abstract}
Santrauka. Sparčiai tobulëjant informacinėmis technologijomis besiremiančioms intervencijoms, pradeda ryškèti tiek teorinės, tiek praktinės problemos. Daug skirtingų sąvokų, jos skirtingai vartojamos. Didžiulè ir pačių IT grįstu intervencijų formų įvairovè. E. sveikatos priemonių poreikis ir populiarumas didẻja dèl jų patogumo, pasiekiamumo, globalumo, mažesnès stigmos ir kitų pranašumų. Tačiau reikia atsižvelgti ir ị kylančius probleminius klausimus - teisinius, etinius, licencijavimo, konfidencialumo ir pan. IT grịstoms intervencijoms esant stresiniams sutrikimams aktualios visos šios problemos, tačiau, tiriant e. sveikatos priemones, reikia atsižvelgti ir ị konkrečių sutrikimų ypatumus. Tyrimai rodo, kad IT gristos intervencijos, skirtos stresiniams sutrikimams, yra efektyvios ir gali prilygti tradicinei terapijai, tačiau reikia atkreipti demesį, kokiais atvejais ir kokios intervencijos yra labiau ar mažiau efektyvios.
\end{abstract}

Pagrindiniai žodžiai. E. sveikata, internetinè intervencija, IT grįsta intervencija, stresiniai sutrikimai. 


\section{ISSUES IN E-HEALTH INTERVENTIONS FOR STRESS}

\section{References}

Al Asadi, A. M., Klein, B., \& Meyer, D. (2014). Pretreatment attrition and formal withdrawal during treatment and their predictors: an exploratory study of the anxiety online data. Journal of Medical Internet Research, 16(6), e152. http://doi.org/10.2196/jmir.2989

Anderson, R. E. E., Spence, S., Donovan, S., March, S., Prosser, S., \& Kenardy, J. (2012). Working alliance in online cognitive behavior therapy for anxiety disorders in youth: comparison with clinic delivery and its role in predicting outcome. Journal of Medical Internet Research, 14(3), e88.

Andersson, G., Carlbring, P., Berger, T., Almlöv, J., \& Cuijpers, P. (2009). What Makes Internet Therapy Work? Cognitive Behaviour Therapy, 38(sup1), 55-60. http://doi.org/10.1080/16506070902916400

Barak, A., Hen, L., Boniel-Nissim, M., \& Shapira, N. (2008). A Comprehensive Review and a Meta-Analysis of the Effectiveness of InternetBased Psychotherapeutic Interventions. Journal of Technology in Human Services, 26(2-4), 109-160. http://doi.org/10.1080/15228830802094429 Bisson, J. I. (2007). Post-traumatic stress disorder. Occupational Medicine, 57(6), 399-403. http://doi.org/10.1093/occmed/kqm069 Eysenbach, G. (2001). What is e-health? J Med Internet Res, 3(2), e20. http://doi.org/10.2196/jmir.3.2.e20

Farvolden, P., Denisoff, E., Selby, P., Bagby, R. M., \& Rudy, L. (2005). Usage and longitudinal effectiveness of a Web-based self-help cognitive behavioral therapy program for panic disorder. Journal of Medical Internet Research. http://doi.org/10.2196/jmir.7.1.e7

Griffiths. (2001). Online therapy: A cause for concern? The Psychologist, 14(5), 244-248. Retrieved from http://search.ebscohost.com/login.aspx?direct=true\&db=psyh\&AN=2001-17415-002\&site=ehost-live

Joinson, A. (1998). Causes and implications of disinhibited behavior on the Internet. Psychology and the Internet: Intrapersonal, Interpersonal, and Transpersonal Implications, 43-60.

Kazdin, A. E., \& Rabbitt, S. M. (2013). Novel Models for Delivering Mental Health Services and Reducing the Burdens of Mental Illness. Clinical Psychological Science, 1(2), 170-191. http://doi.org/10.1177/2167702612463566

Lange, A., Ven, J. Van De, \& Schrieken, B. (2003). Interapy: Treatment of Post-traumatic Stress via the Internet Interapy: Treatment of Posttraumatic Stress via the Internet. Cognitive Behaviour Therapy, 32(September 2011), 37-41. http://doi.org/10.1080/16506070310004935

Litz, B. T., Schorr, Y., Delaney, E., Au, T., Papa, A., Fox, A. B., ... Prigerson, H. G. (2014). A randomized controlled trial of an internet-based therapist-assisted indicated preventive intervention for prolonged grief disorder. Behaviour Research and Therapy, 61, 23-34. http://doi.org/10.1016/j.brat.2014.07.005

Maheu, M. M., Pulier, M. L., Wilhelm, F. H., McMenamin, J. P., \& Brown-Connolly, N. E. (2004). The Mental Health Professional and the New Technologies. The Mental Health Professional and the New Technologies: A Handbook for Practice Today. Routledge. http://doi.org/10.4324/9781410611444

Melville, K. M., Casey, M. L., \& Kavanagh, D. J. (2010). Dropout from Internet-based Treatment for Psychological Disorders. Sports Medicine, 40(3), 271-283. http://doi.org/10.1088/0031-9120/36/6/301

Sarasohn-Kahn, J. (2012). The Online Couch : Mental Health Care on the Web. California HealthCare Foundation, (June), 31.

Sassenberg, K., \& Jonas, K. (2007). Attitude change and social influence on the net. The Oxford Handbook of Internet Psychology. Retrieved from http://www.ncbi.nlm.nih.gov/entrez/query.fcgi?db=pubmed\&cmd=Retrieve\&dopt=AbstractPlus\&list_uids=13059930067094656557related:Lda emDMxPrUJnhttp://books.google.com/books?hl=en\&lr=\&id=zeP1UdZKYfIC\&oi=fnd\&pg=PA273\&dq="common+bond"+"common+identity "\&ots=3Q7uwNZ8Vm\&sig=EE4bZyaeaj8OfBf4NOB10bvOA6k

Spence, J., Titov, N., Dear, B. F., Johnston, L., Solley, K., Lorian, C., ... Schwenke, G. (2011). Randomized controlled trial of internet-delivered cognitive behavioral therapy for posttraumatic stress disorder. Depression and Anxiety, 28(7), 541-550. http://doi.org/10.1002/da.20835

Suler, J. R. (2000). Psychotherapy in Cyberspace: A 5-Dimensional Model of Online and Computer-Mediated Psychotherapy. CyberPsychology \& Behavior, 3(2), 151-159. http://doi.org/10.1089/109493100315996

Wagner, B., Brand, J., Schulz, W., \& Knaevelsrud, C. (2012). Online working alliance predicts treatment outcome for posttraumatic stress symptoms in arab war-traumatized patients. Depression and Anxiety, 29(7), 646-651. http://doi.org/10.1002/da.21962 